\title{
The spectre of Dionysus: play, work, and managerialism
}

\author{
Bogdan Costea, Norman Crump and John Holm \\ Lancaster University, Lancaster, UK
}

\begin{abstract}
Purpose - This conceptual paper analyses cultural changes in the use of the concept of "play" in managerial ideologies and practices since the 1980s.

Design/methodology/approach - The paper uses Koselleck's approach to conceptual history in order to map how play is used in new ways by contemporary organisations. Organisational cultures characterised by "playfulness" and "fun" are used as technologies of self-governance. It explores a variety of sources which show how this metamorphosis of play into a management tool has occurred. Findings - The appropriation of play by management indicates a significant propensity in the contemporary culture of work. A more complex cultural process is unfolding in the ways in which play and work are recombined and intertwined: work organisations are increasingly places where people work more on themselves than they do on work. Work has become a central therapeutic stage set for engineering and managing souls, well-being and even "happiness". In an increasing number of cases, highly managed play settings make corporations resemble frenetic Dionysiac machines in which the Narcissistic modern self seeks an utopia of perpetual fun.

Originality/value - The paper proposes a novel approach to critiques of managerialism. Equally, it offers a new conceptual avenue for the historical analysis of managerial ideas. The result is an original interpretation of the way in which management practices function in their wider cultural contexts.
\end{abstract}

Keywords Work psychology, Management technique, Human capital

Paper type Conceptual paper

\section{Introduction}

Since, the 1980s, management ideas and vocabularies have turned decisively toward the "soft" attributes of human subjectivity. A new equation between corporate performance and the total involvement of the person in work has become the underlying principle of management strategies and tactics. With the advent of "organisational culture", "human resource" and "knowledge" management, managerial practices have focused upon the self as a preferred site for intervention.

Among the favourite techniques deployed in the attempt to enrol the whole person, ludic (play) technologies occupy an undisputed place. From training sessions to entire corporate culture setups, work is being reconfigured through play and, increasingly, work is represented as "play". This paper offers an interpretation of this new mixture between play and work from a cultural-historical perspective. Our analytical approach is informed by existential phenomenology as a philosophical matrix. From it, we draw our main understanding of the cultural relationship between management practices and ideas, on the one hand, and the macro-social and cultural environment of modernity in the twenty-first century, on the other (developed in more detail in Costea et al., 2006).

Our argument is relatively simple: the turn to a "soft" version of "subjectivity" in management over the last 25 years is not just superficial mumbo-jumbo; rather, it reflects profound features of the late modern worldview. Current management ideas

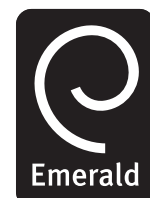

Society and Business Review Vol. 2 No. 2, 2007 pp. 153-165 (C) Emerald Group Publishing Limited $1746-5680$ DOI 10.1108/17465680710757376 
SBR

2,2

154

and practices reflect very clearly the rise of a new "divinity": the "Self" the centre of modern culture and the ultimate reference point of all modern value systems. This new sense of self is omnipresent in the images of what we term "pop-modernity": from reality television, to the workplace, the modern individual has a right to "fun" to pleasure, has an ultimate entitlement to a "24/7" hedonistic existence. It is thus not just any sense of what it means to be a human being that is at stake in the modern assertion of "selfhood" as the ultimate purpose of existence. It is the pleasure-seeking, "happy" smiling, entertained, satisfied, spending customer-person that is central to current modern culture (with its associated economy of mass-production and mass-consumption).

That is why the mysterious figure of the Greek god Dionysus, presiding over the highly ritualised frenzies of mass-consumption, comes readily to mind. Is pop-modernity the time of Dionysus' return? Is the Taylorist-Fordist serious and self-abnegating work ethics being replaced by a more "organic" and more productive holistic ethics in which going to work is "good for you"? Are managerial ideologies centred around a new idea: that working on work is unsatisfying, and that working on one's self (using multiple motivational therapies) is perhaps the ultimate source of creative liberation (the key to "commitment" with all its variations)? Is the managerial class brainwashing its subjects once again? Or are the frenetic rhythms of the "work hard/play hard" corporate cultures the portents of a new god, a Narcissistic-Dionysian Self-Divinity, the $\mathrm{Me}, \mathrm{Me}, \mathrm{Me}$-god of shopping malls and endless television channels, a pseudo-divinity not of mystery (like the ancient Greeks'), but one celebrating the bright lights of super-pubs and disco-clubs, a divinity whose effervescence is no longer creative of life, but rather passive and purely consuming?

We suggest that the managerial turn to subjectivity is a reflection of the modern self's turn to a phantasy-world whose direction is perhaps best captured by Bruckner's (2000) image of an "utopia of fun" in which no sense of self-sacrifice, of loss of self, of giving of one's self, will characterise the world of work organisations. Corporations will (as, in fact, they already do in many relevant cases) resemble, in turn, large playing fields populated by "perpetually young" generations of "happy workers". Managerialism (both as institutional formula and as new idiom), we argue, is one of the key sites where cultural processes unfold momentously in this phase of modernity. Thus, in our view only a cultural hermeneutic can provide a solid grasp of the fundamental relationships between business organisations and the societies in which they have become central institutions.

The paper will, first, spell out our conceptual assumptions. Then, we will introduce some examples of the rise of play at work (as instances of the new semantic field in which managers make sense of their own work). Finally, we will construct a cultural-historical critique of this phenomenon.

\section{Concepts in context: Begriffsgeschichte ("history of concepts") as an existential phenomenological strategy for historical work}

In the next section, we will present some examples of the way in which the concept of "play" has undergone fundamental semantic changes in relation to the concept of "work" in contemporary managerialised organisations. But first we want to outline briefly our conceptual framework. The analysis presented is inspired by a school of historical work known as Begriffsgeschichte (in German) or "history of concepts" 
in English, whose hermeneutic strategies have been explained in more detail in Costea et al. (2006). This school of historical analysis has developed in West Germany after the World War II. Its main figure has been Koselleck whose ideas are available in English in two collections published in 1985 and 2002. Koselleck's (1985, 2002) work draws on other historians' (such as Otto Bruner's and Werner Conze's). For this paper, however, the most important theoretical influence on Koselleck's thinking is Martin Heidegger's existential phenomenology.

Koselleck's work centres around fundamental questions of sociocultural history: how does language (writ large) mediate historical processes? What is the role of various vocabularies in the history of culture? How does language (as a collective accomplishment) relate to human existence (collective and individual)? How does "discourse" in other words, relate to the "social"? In Koselleck's perspective, we can begin to answer such questions if - and only if - we take a position about the metahistorical nature of history as the manifestation of human existence in the world. We need a philosophy of history to begin with. His own position was informed by Heidegger's (1962) key contributions to phenomenology in Being and Time. Koselleck was entirely right to realise that twentieth century philosophy offered no significant discussion of the "historical". It was only Heidegger who contributed a genuine philosophical elaboration of the nature of the "historical" as the central specific feature of being human. Of all that philosophy had to offer Heidegger's was the only systematic philosophical work that could offer a conceptualisation of the nature of history as an ontological given (a datum) of human existence.

Koselleck became an existential phenomenologist in the field of history. He assimilated Heidegger's central contribution to philosophical anthropology: namely, that time is the foundational dimension of being human, that to be human is to be in time, to exist in a historical horizon in which past, present, and future are continuously forming our awareness of our being finite. The nature of human existence is framed, for both Heidegger and Koselleck, by man's awareness of finitude, of mortality. This sets Homo sapiens aside from all other species of living creatures and transforms it into a historical being, a being whose realisation of temporality frames its search for meaning in life.

Awareness of death (Heidegger's pivotal point) is not, however, a morbid feature of human being; rather, it is what opens up history to man. We have only one certainty in life: that we are finite in time. We only know that we were born, and that, one day, we will die. What is more fundamental to our condition as meaning-seeking (hermeneutic) creatures is that both these moments are just as mysterious, as shrouded in unknowability, as they are certain. Certain only of something whose full meaning we cannot grasp: this seems to be the dynamo that sets human existence alight, that makes it different from any other species' that led to the active search for the meaning of life which has, in turn, "switched on" History as man's creative and transformative trace in the universe.

Finitude is life's motor. By attempting to cope with the meaning of the impending, yet mysterious, "end" every human being is opened up to a series of continuous questions, which mark every single moment of every single human life: what am I? Who am I? How should I live in the world? How should I be facing others in my search for a meaningful life? What is a "good life"? How should I treat others when time is limited and I am concerned for my existence? How do I want to be treated by others

\section{The spectre of Dionysus}

155 
SBR

2,2

156

in turn? And so on. These elementary questions (long forgotten, in Heidegger's view, by all modern philosophers) form the historical horizon of our everyday life. We account for them (consciously or unconsciously) with our every gesture, with our every choice. We speak and make sense because we frame our answers to such questions, to one another, and in doing so, we are bound up with the linguistic nature of human society. We are not simply communicative beings; all other species are. We are discursive beings; our communications are creative (not mechanical) accounts of our understanding of our historical position; we reason through language (logos is both language and reason) by constructing narratives which represent our understanding of our past, present, and future. These narratives allow us to live on, to make sense of what we are; in a very serious sense, we exist through language, not language through us. We do not make language like we make computers; rather, we can only make computers (themselves "speech machines" as Heidegger put it) because we are enabled by language. Language makes us what we are as existential beings. We are creatures of permanently anticipated possibilities, forever "worried" that we might not make good use of life itself. But this "worry" this concern, makes the human, Heidegger (1962, p. 185) argues, “... constantly 'more' than it factually is”. Macquarrie (1973, p. 32) paraphrased it: "Man is possibility. He is always more than he is, his being is never complete at any given moment. He therefore has no essence as an object has". This fundamental tension is the "motor" of the permanent working out of the "historical" as an interplay between interpretations and possibilities unfolding in time.

Koselleck takes these philosophical ideas and transforms them into a historical analytical strategy by a simple gesture: he argues that human history is "caused" by the way in which existential "time" (our awareness of our own mortality) shapes human everyday lives as a continuous interpretation of experience (of the past), and expectation (anticipation of the future). Articulations of experience and anticipations of the future are open to our (always tentative) interpretations. Here, Koselleck introduces his other key contribution: such interpretations show their full meaning in certain foundational concepts (which are not simply words in a limited sense) which embody our sense of experience and expectation as we move through time. We make sense of our passing through time using various key concepts in which we tell our stories about the past, the present and the future. Such key concepts are, nowadays for example, "freedom”, "personal fulfilment”, "faith”, "fun”, "progress", "success", “enterprise”, etc. They are inherently ambiguous because they touch the foundations of our personal lives, collectively and individually, to the extent that they are giving meaning and direction to our sense of what our existence means. Other words in our vocabulary are not concepts in this concrete historical sense; for instance, words such as "tennis", "apricot" or "lawnmower" do not carry any of the existential ambiguity and openness needed to frame the sense of life in any meaningful way (of course, this is a gross oversimplification in the name of illustration).

For the historian's work, one of the key aspects is to understand how concepts are used to shape human action, institutions, and practices. For example, how do we relate the philosophical concepts of the Enlightenment with the practical events of the French Revolution or American Independence, and with modern life more generally? How does freedom as a concept mediate the actions of various historical agents? How does progress shape our expectations of the future of human existence on an endangered planet? If we use (as we do) the concept of "progress" to explain modernity as an 
experience (we made so much progress over the last 500 years, or over the twentieth century, etc.), and if we carry its meaning into an expectation of the future, should we then safely assume that something will be developed to sort out some of the very concrete problems we are creating to our present actions? How did such a key concept like "progress" arise, change meaning, and in turn change history itself?

To answer such questions. Koselleck and his colleagues buckled down and produced elaborate encyclopaedic works mapping, for example, the key concepts which marked the formation of modern German society between 1750 and 1850 . Equally effectively, they analysed the concepts which mediated the rise of modern French society. The lessons of their approach are useful for analysts of management ideas in equal measure. Our question here is framed in such a way: is there a change in managerial action brought about by a change in the way in which the concept of "play" has been utilised in managerial vocabularies since the 1980s?

\section{Play at work, or play as work?}

We will attempt to offer a brief phenomenological reading, in Koselleck's manner, of the concept of play in recent managerial ideology. We argue that, this concept has undergone a transvaluation from a simple, rational, and rather marginal, method of recreation, needed to enhance productive abilities, to a wider and more central metaphor of personal and organisational life. Basically intolerable to the logic of mass-production assembly lines of the early 1900s (misbehaviour), play became acceptable as a regenerative distraction (especially in the tense circumstances of the two world wars). However, play and work remained ethically separate spheres of the lifeworld and their co-presence was always a form of transgression and in need of careful separation: "serious work" and "frivolous play" could only come together as either subversion (misbehaving), or as lateral, extramural, passive, non-productive recreation of individual and collective working potential.

The post-war period, dominated by "systems rationalism" (Barley and Kunda, 1992), saw an expansion in the use of play as a managerial technology required for the stimulation of learning and innovative processes. The use of play as a managerial technology has increasingly become more central ever since, especially post-1980s, when a rather profound shift in the architecture of management ideologies occurred focusing on the self.

In the 1980s and 1990s, subjectivity (the self with its intimate grammars) became the central platform of managerial work and self-understanding. Managerial ideologues produced endless series of new categories anticipating the liberation of a "cornucopia" of human resourcefulness. This turn to subjectivity found in play a theme allowing a polyvalent justification of the general call to mobilise all personal resources in the service of "self-assertion" as the key to productivity. For the first time, it seems, managerial discourses not only emphasise ideas of productivity, corporate performance and profitability, but also additionally focus on the opportunities work provides for the celebration of the "self". The new logic is that from self-affirmation economic value will emerge: this has ever since been the core rhetorical stratagem of the thesis that "strong organisational cultures" will lead to performance. And this has also been the vector which changed the identity of management work: managers began to see themselves as creators and "leaders" of organisational cultures, instead of simple administrators and controllers of production systems.

\section{The spectre of Dionysus}

157 
SBR

2,2

158

Among the changes brought about by this ideological shift is a long series of novelties in the way the concept of "play" has been mobilised in managerial use. New ways of looking at "play" emerged as the new key to set free the "productive innovative - creative - learning self" (the new "human resource"). The sequence of the argument was as follows: "business excellence" is generated by "strong organisational cultures"; in turn, strong cultures require commitment; commitment can only be engendered through participation; and one of the most effective contexts for creating participation is the representation of work as play. Play is the ultimate effortless mediator of intense involvement in work. As Nietzsche (1956, p. 23) shows in his analysis of Dionysiac ritual, in the social effervescence of play:

... the slave emerges as a freeman; all the rigid, hostile walls which either necessity or despotism have erected between men are shattered. Now that the Gospel of universal harmonies is sounded, each individual becomes not only reconciled to his fellow but actually at one with him.

All kinds of modulations of the ludic found their way effortlessly into the new managerial idiom. A new semantic field grew around the concept of "play" and a new set of themes associated with work as a playful part of life became legitimate managerial currency. A key example in this process is Deal and Kennedy's (1982) book entitled Corporate Cultures: The Rites and Rituals of Corporate Life, a piece belonging to a long list of soul-searching, new (at the time) kind of management consultancy material which marked the early 1980s in America. This contribution was one among many which, during a crisis of managerial legitimacy, explained corporate success on the basis of dynamic types of organisational cultures. Dedicated to "Tom Peters, Willie Nelson, and others like them" the book was one of the successful attempts to inspire American managers in a new "search for excellence". Alongside Tom Peters and other evangelising management consultants, Deal and Kennedy's aim was to provoke managerial circles to rethink their legitimacy and reconfigure their roles. The result turned out to be quite spectacular: a key shift occurred in the general programmes of managerial ideology. Human subjectivity in a multiplied set of guises became the new focus of managerial ideology and practice. It helped American and European managers to emerge from a process of radical transformation within their economies and organisations as the rightful stewards of a new "object" - the "strong organisational culture". This "cultural turn" has been discussed widely since (Barley and Kunda, 1992; Alvesson, 2002). Here, we want to emphasise only certain aspects of it.

In Deal and Kennedy's (1982, pp. 113-16) typology of success stories of American corporations (success based on fostering a strong and healthy "corporate culture"), one type is important: the "work hard/play hard" culture. In their view, this style characterised organisations with "rapid" feedback and reward cycles operating in what appeared as low-risk business sectors: especially sales, services, software production. Characterising them as "hyperactive" team-based, sales-orientated, and customer-focused, Deal and Kennedy began to use a new vocabulary to describe the potential of their "human capital". They used "play" to describe the way in which hyper-active cultures were regenerated. Using a common expression ("work hard, play hard"), they saw a new source of cultural regeneration in a new social "glue" consisting of fun, humour, jokes, friendliness and games at work (Deal and Kennedy, 1982).

But they did not understand the appeal of this cultural style beyond this simple functional (and a historical) explanation. Nor did they reflect upon their own borrowing 
of an expression ("if you work hard you are entitled to play hard") describing a new sense of entitlement running through the centre of the ethos of mass-consumption societies during the last few decades of the twentieth century. This is surprising since they do note that "These cultures are cultures of young people who are looking for places to prove their worth" (Deal and Kennedy, 1982, p. 116). Indeed, the "work/play hard culture" became very desirable and indeed possible as Atlantic economies became (perforce) converted to service economies and many organizations sought to mobilise commitment and hitherto "hidden" human potential through the new idioms of playful, participatory cultures. The workforce was equally ready to embrace these cultures: new generations feeling bound and entitled to, life-long consumption found the opportunity to expand the sphere of enjoyment seductive (in general, the languages of organisational culture - quality, excellence, empowerment, participation, learning, development, commitment, knowledge work, self-actualisation, etc. - turned out to be very seductive). This proved to be a key cultural move: it introduced a formula which bridged organisational and extra-organisational cultures. The insertion of "hard play" (as an entitlement in compensation for "hard work") in the legitimate sphere of management marked the emergence of new way of combining themes from the sphere of work with themes from the sphere of leisure.

Over 20 years, the result has been remarkable. For new generations of western managers, the link between hard work and hard play became a taken-for-granted ingredient of commitment to a strong organisational culture. A case in point is Egg:! the telecom bank, whose central operation in Derby (UK) is run precisely on the principle of a "work hard/play hard" culture.

Egg:ı's call centre, arguably the equivalent of the industrial revolution's sweatshops, has managed to invent itself so that, at least on the surface, it appears to be anything but a latter-day sweatshop. On the contrary, it is an archetypal "work hard/play hard" culture (possibly surpassing Deal and Kennedy's own anticipations). Egg:I's call centre is a large warehouse space transformed into an open plan office in which work and play areas are indistinguishable (desks, pool and football tables are interspersed) (Myerson and Ross, 2004). A special cardboard shape (two circles making two smiley faces, holding hands) with a caption which reads: "happy egg:! people" captures the new identity of the "egg:ı person". "Egg:ı people" is the term staff use to describe themselves: "it is being an individual, first and foremost, letting your personality shine through" (an egg:! employee). Employees are proud to be "egg:! people" they have a "pride and passion" for the company, they themselves use the company products, they have even formed "egg:! couples" (who define almost their entire lives through the company); they are their own customers. It is perhaps in the very idea of "happy egg: people" that the link between production and consumption, play and work, is most clearly evident. This case is discussed in detail in Costea et al. (2005).

Egg:! however, is only the beginning of the impact that play has had on organisations. Deal and Kennedy's work hard/play hard culture in many respects only scratches the surface of efforts to manage the "soul" of the worker. Over the last two decades, an entire new body of managerial literature developed around the human subject as the newly found focus of managerial action. This literature seeks to redefine play from a tool for managing culture (and, subsequently, how employees engage with

\section{The spectre of Dionysus}

159 
SBR

2,2

160 the organisation, as in the case of egg: 1 ), to recasting play as a fundamental ingredient of productivity.

One example is an entire journal devoted to the subject. Amongst the contributors to the Journal for Quality \& Participation is Berg $(1995,1998,2001)$ who has published since 1995 papers on play and the "playful spirit at work". Berg (1995) reframes "play" and "fun" as the modes of being and working required to deliver what corporations seek from their people in their value statements: "It is not the quick fixes (summed up as three-letter acronyms: MBO, CQI, SPC, QFD, TQM, QOS, BPR) [which] have failed to achieve long-term lasting improvements" (Berg, 1995). Rather, she argues:

... it might be time to look to a four-letter word: PLAY for improvement. If that's too radical a change for you, you might try an old three-letter word, FUN. When work isn't fun, people do the minimum they need to survive until they can leave work and have fun outside of work. Many companies now realize that playful creativity and meaningful work can combine to create organizations where people not only love to come to work, but also obtain superior results (Berg, 1995).

Companies who see "quality, flexibility, speed and innovation ... [as] essential to compete successfully in the global marketplace” will understand, in Berg's (1995) view, that it is only those:

... that provide a fun, pleasant, supportive work environment [who] will have the edge in attracting superior people who view work as a joy and have abundant energy, enthusiasm and talents to focus toward organizational goals. They will also unleash all of the undiscovered innovators-in-waiting who have worked there for years, with no one, including themselves, having an awareness of how much more they could contribute.

We spend too much time at work not to have fun, while we're there; when we wait until we finish our work to play we run the risk of living less joyful lives and operating less successful companies.

Berg's (1998) contribution is more radical in tone: she no longer needs to prove her point about play since, she starts by writing, "BUILDING FUN, PLAY, AND HUMOR INTO THE workday is a proven method of unleashing creative ideas". Moreover, she no longer accuses corporations of missing this point. Rather, in her view, "Many organizations now realize that playful creativity and meaningful work can be combined to produce exceptional results" (Berg, 1998). The point of the paper is to, radicalise the search for play and fun as modes of being of the new human resourcefulness. She exhorts corporations to "transcend terminal seriousness" to "trash taboos" and to "get wild" (Berg, 1998).

In 2001, her original contribution (Berg, 1995) was re-published by the journal with the headline: "A Journal classic about the power and spirit play can bring into the workplace." from which one can "Learn how to take advantage of fun" (Berg, 2001). The same journal published a large number of similar papers in which the links continued to be made and amplified between high performance, excellence, or "artistry" (Richards, 1995), on the one hand, and "joy" (Richards, 1995), or "enjoyment" (Townsend and Gebhardt, 1995), the "respiriting of organisations" (Epps, 1995), the use of games and "scouting" (Holder, 1995).

A whole series of new books are also dedicated to the subject of "play" at work. For example, in his Serious Play, Schrage (2000) links play with the "new economics of innovation". The theme has already been described in the examples above: creativity, innovation and playfulness go hand in hand. Moreover, (the eternal) Tom Peters is: 

thread of modern management thought. In short, I love this book! It is absolutely an original ... And it is absolutely right (Schrage, 2000 - front dustcover).
... ready to declare Michael Schrage's Serious Play a seminal contribution to the 100-year

The spectre of Dionysus

In 2004, and in more uncompromising terms, Pinault (2004) published his Play Zone. Its subtitle is relevant: 6 Principles for Unleashing the Hidden Value of Your Company. The thesis is that the world of business is chaotic, complex to such an extent that no linear form of rationality could attempt to comprehend and act in this complexity. What is interesting is Pinault's prose: as opposed to Schrage who repeats his linear logic of creativity and playfulness, Pinault's book is in itself chaotic, jumping from one theme (and one style) to another, using paradoxical language and an artificial tone that makes it look written by a computer programme. Pinault works partly as a consultant to the LEGO company where he advises on the elaboration "LEGO SERIOUS PLAY" toy sets for developmental events for different themes: project management, strategy making, teambuilding, etc. (available at: www.seriousplay.com (accessed February 2007)). His message is radical: unleashing the power of play through the creation of "play zones" in organisations is the key to living in the future world of business.

Another volume belongs to Kane (2004) (jazz musician, management consultant, activist and editor of the online Play Journal) entitled The Play Ethic, subtitled $A$ Manifesto for a Different Way of Living. His range of interests is wide and his main references are just as wide: from MTV (the music channel) to the work of philosophers such as Carse (1986) and psychologists such Csikszentmihalyi (1975), from Ricoeur to Zizek, or from Steven Rose to David Deutsch. Kane (2005a) links play with everything from arts and media, to business and work, lifestyle and education, politics and spirituality. The question here is no longer whether there can be any suspicion of play being enlisted by business interests to colonise the lifeworlds of employees, but one of extent. Indeed, Kane's work is a different kind of cultural product altogether.

On Kane's (2005b, our emphasis) consultancy site, we read:

Moving all participants from the narrow expectations of a workaday life, the Play Ethic opens up the infinite possibilities arising from full engagement of heart, body and soul.

The claim is indeed extraordinary. The idea of "infinite possibilities" comes to Kane from a small work of (so-called) philosophy: Carse's (1986) Finite and Infinite Games. Written in somewhat aphoristic style, Carse's (1986, pp. 7-8) message is that life should be seen as an infinite game in which "Infinite players cannot say when their game began, nor do they care. They do not care for the reason that their game is not bounded by time." An important part of this infinite game is the discovery of "infinite sexuality" as expression of one's "genius" manifest in infinite "sexual desire" which binds partners but not in the traditional systems of family relationship; rather they meet on another plane where there is continuous enjoyment.

\section{The reconfiguration of management ideologies and the culture of modernity}

These are but a few of the myriad of modalities in which the concept of "play" has been integrated in the managerial mythology of work. In its literature and in its practices, 
SBR

2,2

162

managerialism has deployed play as a key ingredient of its new programme of engendering organisational order through subjectivity.

Kane's highlighting of Carse's move from the finite to the infinite is important here. Arguably egg:! with its "egg:! people" and so forth, was only ever concerned with managing a finite resource - reducing the mechanical nature of call-centre work. In this sense, play at "egg:!" while demonstrating an excess, is more about disguising he relations of capital - "being your own customer" does not collapse the divide between production and consumption, rather it makes it all the more obvious. In some respects, play at egg:! works at a distance. Carse, and Kane and Pinault, on the other hand, see play unlocking an infinite creative capacity that collapses the gap between production and consumption, at least in terms of the production and management of worker subjectivities.

In this guise, play extended its sphere from a mere recreational moment, to a productive context. Contributions such as Babb's (1966), Newstrom's (1980), Deal and Kennedy's (1982), Kaagan's (1999), or Schrage's (2000) illustrate the historical sequence of this repositioning. For them, play is effective because it engenders mimesis: assimilation and reproduction of behaviours in game-mediated learning settings (flight simulators can be used to train pilots, therefore business games and simulations can work in a similar fashion), or assimilation and reproduction of certain dimensions of organisational culture (such is Deal and Kennedy's “work hard/play hard cultures” or Schrage's "prototyping" as an activity which generates and regenerates productive innovation and productive organisational dynamism).

The key shift occurs in the 1990s: "play" and "playfulness" change from a mimetic-productive device to a complex set of modes of being and "feeling" at work. Pinault and (emphatically) Kane suggest new implications. First, the constituency of "players" in organisations expands: from training settings and innovative processes confined to those who design, manage, or "think strategically" nowadays all organisational members can and ought to play. Pinault makes this plain: the new "cultures" are for everybody and are everybody's. Thus, if there is to be play in organisations, then its constituency is the entire membership. Secondly, play has not only expanded its "quantitative" social sphere; it has also changed its quality. In Pinault's and Kane's texts, play at work marks a shift in the ethos of life. Play is no longer a secondary aspect of life; it is pushed into a central position as an ultimate modality of mobilising organisational and personal resourcefulness.

A reappraisal of the cultural-ethical value of play has occurred leading to its transvaluation as a mode of being at work. In Pinault and Kane, for example, new combinations emerge: on the one hand, they construct an image of a world which is complex and chaotic because it is the outcome of an intractable play of forces and energies; on the other hand, they suggest that the human subject too should rediscover its true nature, one in which the life-giving force is "play" or being "playful" (in other words, to live life to the full, to be fully what one can be - a favourite motif of Maslowian self-actualisation - the subject ought to treat life as play).

Pinault and Kane also establish a new relationship between play and the nature of the world. For them, playfulness is not just an "optional" feature of work. It becomes compulsory because the world itself is a play of intractable forces. This is evident in their rejection of the dull and uncreative "seriousness" of the Protestant work ethic (expressed in its formal rationality) in favour of a worldview emphasising the 
"chaotic", "uncertain", "complex" and "fast changing" nature of life itself. This requires a "new (personal) integrity" a substantive new way of integrating one's self in the world. Play becomes the new rational mode of facing this (re)integration in a world where networking, connectivity, virtuality, globality, and so on, are the new dimensions of existence.

The transvaluation which takes place here is that "play" becomes a serious proposition. No longer are play, enjoyment, or fun (as its contemporary corollaries) mere frivolities and self-indulgence. Schrage and Pinault present them as "serious" because they have become both entitlements for organisational members and central ingredients of "performativity". This new, "total" kind of "play" suggests the legitimate expectation of a new horizon of being at work. In climactic promise, Kane anticipates no less than "infinite possibilities". What is the cultural import of this expectation/desire? Is it new?

The new types of reference made to play in managerial literature and practices, the omnipresence of the vocabularies of fun, enjoyment and so on, have opened up the everyday relationship between self and work to new possibilities. Boundaries between work and play become blurred. Equally important is the new purpose of playing at work: play is not another tool for work intensification; it is an "entitlement" of the "hard working" self. Productivity follows naturally from an overflow of personal well-being. Unsurprisingly, organisations blend ludic practices with what is termed "wellness at work" (relaxation, "positivity" fitness, emotional well-being, etc. are all part of the new idiom of managerialism - Costea et al., 2005).

The experience of work as self-renunciation, drudgery, and as a context in which being serious meant "not enjoying oneself" (a reference to the now obsolete Protestant work ethic made explicitly in Kane's principles for New Integrity) should be replaced in "playful" organisations by the opening up of a horizon in which one expects work (as human action) to be delivered free from tension, suffering, and a sense of self-sacrifice. Rather, the new ethos of work finds a central place for "having fun" (leading, by implication, to new levels of liberation). Perhaps, more fundamental is the indication contained in these uses of play that a new understanding of the horizon of life is on the brink of emergence: the anticipation of life with no foreseeable end, or, at least, promising endless youth through a perpetually preserved and active "inner child".

\section{Concluding remarks}

To conclude, we argue here that over the last 25 years a change has occurred in the use of "play" in managerial literature - a change which indicates a wider shift in the focus of managerial ideologies and practices. Over this period, the changes which have taken place in the cultures of management and organisations have been accelerated by an insistence on a new equation between the ethics of continuous self-work and productivity. What is at stake in this new expectation of "work" is no less than a radical change in the measure of the relationship between the subject and object of work. Work has been transformed through managerial ideologies since the 1980s into an occasion to experience a series of quasi-Narcissistic interventions on a "continuously improving self". Working on one's self, on one's subjectivity, "performing" has become the measure of work itself. Work on self appears more important then work on work. It is a paradox that the human subject becomes the central aspect of management ideologies and practices in an age when cost and profit are so acutely central in the discourses of

\section{The spectre of Dionysus}

163 
SBR

2,2

164

accountability and corporate performance. Yet technologies of self-work have become so successfully disseminated in contemporary organisations (with the most extravagant targeting the managerial cadre first and foremost).

The thesis of cynical manipulation of an unsuspecting workforce by a knowing corps of executives cannot explain the cultural force of the new managerial practices in which play occupies such an important position. Rather, it seems to us important to ask, in conclusion, whether the effervescence of playful organisational settings is not a sign of the wider cultural context of high mass-consumption in which the Narcissistic-Dionysian figure of the "kidult" entitled to endless fun, carries the power of shaping the phantasies of identity and expectations of modern work?

\section{References}

Alvesson, M. (2002), Understanding Organizational Culture, Sage, London/Thousand Oaks, CA.

Babb, E.M. (1966), Management Games for Teaching and Research, Educational Methods, Chicago, IL.

Barley, S. and Kunda, G. (1992), "Design and devotion: surges of rational and normative ideologies of control in managerial discourse", Administrative Science Quarterly, Vol. 37, pp. 363-99.

Berg, D.H. (1995), "The power of a playful spirit at work", Journal for Quality \& Participation, Vol. 18 No. 4, pp. 32-8.

Berg, D.H. (1998), “The power of play”, Journal for Quality \& Participation, Vol. 21 No. 5, pp. 54-5.

Berg, D.H. (2001), "The power of a playful spirit at work", Journal for Quality \& Participation, Vol. 24 No. 2, pp. $57-63$.

Bruckner, P. (2000), L'euphorie perpétuelle. Essai sur le devoir de bohneur, Grasset et Fasquelle, Paris.

Carse, J.P. (1986), Finite and Infinite Games: A Vision of Life as Play and Possibility, Random House (A Balantine Book), New York, NY.

Costea, B., Crump, N. and Holm, J. (2005), "Dionysus at work? The ethos of play and the ethos of management", Culture and Organization, Vol. 11 No. 2, pp. 139-51.

Costea, B., Crump, N. and Holm, J. (2006), "Conceptual history and the interpretation of managerial ideologies", Management and Organisation History, Vol. 1 No. 2, pp. 159-75.

Csikszentmihalyi, M. (1975), Beyond Boredom and Anxiety: The Experience of Play in Work and Games, Jossey-Bass, San Francisco, CA.

Deal, T. and Kennedy, A. (1982), Corporate Cultures: The Rites and Rituals of Corporate Life, Addison-Wesley, Reading, MA.

Epps, J. (1995), "Respiriting organizations", Journal for Quality \& Participation, Vol. 18 No. 4, pp. 40-7.

Heidegger, M. (1962), Being and Time, Basil Blackwell, Oxford.

Holder, R.J. (1995), "Requisite for future success ... discontinuous improvement", Journal for Quality \& Participation, Vol. 18 No. 5, pp. 40-5.

Kaagan, S.S. (1999), Leadership Games: Experiential Learning for Organizational Development, Sage, Thousand Oaks, CA.

Kane, P. (2004), The Play Ethic: A Manifesto for a Different Way of Living, Macmillan, London.

Kane, P. (2005a), Play Journal, available at: http://theplayethic.typepad.com (accessed February 2007). 
Kane, P. (2005b), New Integrity, available at: www.newintegrity.org/new_integrity.htm (accessed February 2007).

Koselleck, R. (1985), Futures Past: On The Semantics of Historical Time, MIT Press, Cambridge, MA.

Koselleck, R. (2002), The Practice of Conceptual History: Timing History, Spacing Concepts, Stanford University Press, Stanford, CA.

Macquarrie, J. (1973), An Existentialist Theology: A Comparison of Heidegger and Bultmann, Pelican, London.

Myerson, J. and Ross, P. (2003), The 21st Century Office, Rizzoli International Publications, New York, NY.

Newstrom, J.W. (1980), Games Trainers Play: Experiential Learning Exercises, McGraw-Hill, New York, NY.

Nietzsche, F. (1956), The Birth of Tragedy and the Genealogy of Morals, Doubleday Anchor Books, New York, NY.

Pinault, L. (2004), Playzone: Unlock your Creative Genius and Connect with Consumers, Harper Business, New York, NY.

Richards, D. (1995), "Artistry and the experience of joy", Journal for Quality \& Participation, Vol. 18 No. 7, pp. 6-10.

Schrage, M. (2000), Serious Play, Harvard Business School Press, Boston, MA.

Townsend, P. and Gebhardt, J. (1995), "Work and enjoyment", Journal for Quality \& Participation, Vol. 18 No. 7, pp. 10-12.

\begin{abstract}
About the authors
Bogdan Costea is a Lecturer in the Department of Organisation Work and Technology, Lancaster University. Recent publications include "Conceptual history and the interpretation of managerial ideologies" in Management and Organisation History, 2006, Vol. 1 No. 2, pp. 159-75; and "The Ethos of Business in H.G. Wells' Novel The Wife of Sir Isaac Harman" Forthcoming in the Journal of Management History, 2007, Vol. 13 No. 1. Bogdan Costea is the corresponding author and can be contacted at: b.costea@lancaster.ac.uk

Norman Crump is a Lecturer in the Department of Organisation Work and Technology, Lancaster University. His current research interests are concerned with the role of technology in changing the "caring" organisations. He has a continuing interest in developing cultural and historical interpretations of different forms of managerial activity with particular reference to Human Resource Management.

John Holm is a Doctoral Candidate in the Department of Sociology at Lancaster University. His interests focus upon how changes in managerial and organisational thought impact the design and use of space, and the recursive nature of this relationship. Recent publications include "Office design and business performance" a report for the Commission for Architecture and the Built Environment.
\end{abstract}

To purchase reprints of this article please e-mail: reprints@emeraldinsight.com Or visit our web site for further details: www.emeraldinsight.com/reprints 